\title{
STRENGTH, LOAD-DEFLECTION BEHAVIOR AND IMPACT RESISTANCE OF TWO-WAY SLAB FOR CONCRETE INCORPORATING WASTE ALUMINUM FIBERS
}

\author{
SHEELAN MAHMOUD HAMA ${ }^{1}$ \\ College of Engineering, University of Anbar-Iraq
}

(Accepted for Publication: December 8, 2020)

\begin{abstract}
This research investigated about the effectiveness of waste aluminum results from waste cans of gassy drink, as fibers in concrete. strengths, load-deflection behavior under flexural load and impact resistance under low velocity repeated impact load were investigated. Two length of fibers were examined $40 \mathrm{~mm}$ and $20 \mathrm{~mm}$ for $0 \%, 0.5 \%, 0.75 \%$ and $1 \%$ fibers content. Results showed that compressive strength has inconsiderable affected by adding fibers while splitting tensile strength, modulus of rupture and impact resistance for concrete incorporating aluminum fibers especially for $0.75 \%$ and $4-\mathrm{mm}$ fibers have clear improvement. Compared to experimental results, ACI equation underestimated the tensile strength of fiber concrete. Load -deflection of beam with fibers showed a more ductile behavior at failure under flexural load compared to reference one. Bond strength improved by adding aluminum fibers. Slabs that incorporating aluminum fibers showed a higher energy absorbed, less deflection and smaller cracks width at failure than the one without fibers under impact loads. From results, one can see that mixes with 0.75\% fibers showed a best performance compared with other mixes. Finally, the $\mathbf{4 0} \mathbf{~ m m}$ fiber was more effective in improvement in concrete resistance than $20 \mathrm{~mm}$ fiber length.
\end{abstract}

KEYWORDS: Aluminum fiber; bond strength; impact resistance; energy capacity; load-deflection behavior

\section{INTRODUCTION}

$\boldsymbol{F}_{\text {concrete containing fibrous material, }}^{\text {ibers Reinforced Concrete (FRC) is a }}$ which increases its structural integrity. FRC can be utilized in order to control cracks propagations due to plastic and drying shrinkage. Some types also improved abrasion-, impact-, and shatter-resistance of FRC. In the last few years researches about using fibers which are produced from waste material like PET plastic [Fraternalia 2011, Pelisser 2012, Hama 2017, Aziz et al 2018, Silva and Prasanthan 2019, Aziz et al 2019], metallic plastic [Ankur et al 2017, Bhogayata and Arora 2018], steel wire from waste car tire are increased [Hama 2015]...etc. In addition, fibers can produced from waste aluminum metallic cans of gassy drink. Some researchers studied the effect of this kind of fibers; they found an clear improvement in splitting and flexural strength but slightly improving in compressive strength [Murali 2012, Behera and Behera 2015, Suji et al 2017]. Another research investigated about the optimum content of wasted soft drink can which can be add as fiber in lightweight concrete. They found that $15 \%$ volume fraction of this type of fiber [Indradi 2019]. Behera et al [2018] used a small volume fraction of this type of fibers; $0.1 \%, 0.2 \%, 0.3 \%$, and $0.4 \%$. He found an increase in compressive strength for $0.3 \%$ with improving in both splitting and flexural strength. However, slump and absorption decreased with increasing of fibers content. 
From researches above, one can see that most of these researches are about mechanical properties; compressive, splitting and flexural strength and it is hard to find effect of this type of waste fibers (aluminum fibers) on impact, bond strength and load deflection behavior of concrete. Then the primary objective of present research is to evaluate influence of waste aluminum fibers on the bond strength, impact resistance and energy absorbing capacity of reinforced concrete. Besides load deflection behavior under bending, compressive, splitting and tensile strengths were investigated.

\section{MATERIAL, MIX PROPORTIONS AND TESTS}

Ordinary cement type I was used with sand as fine aggregate and gravel as coarse aggregate those material are satisfied Iraqi specification No. 5 and 45 respectively. Gassy drink cans were collected and shredded to slides to be used as fibers with 20 and $40 \mathrm{~mm}$ length, $2 \mathrm{~mm}$ width and $0.25 \mathrm{~mm}$ thickness, see Figure 1 .

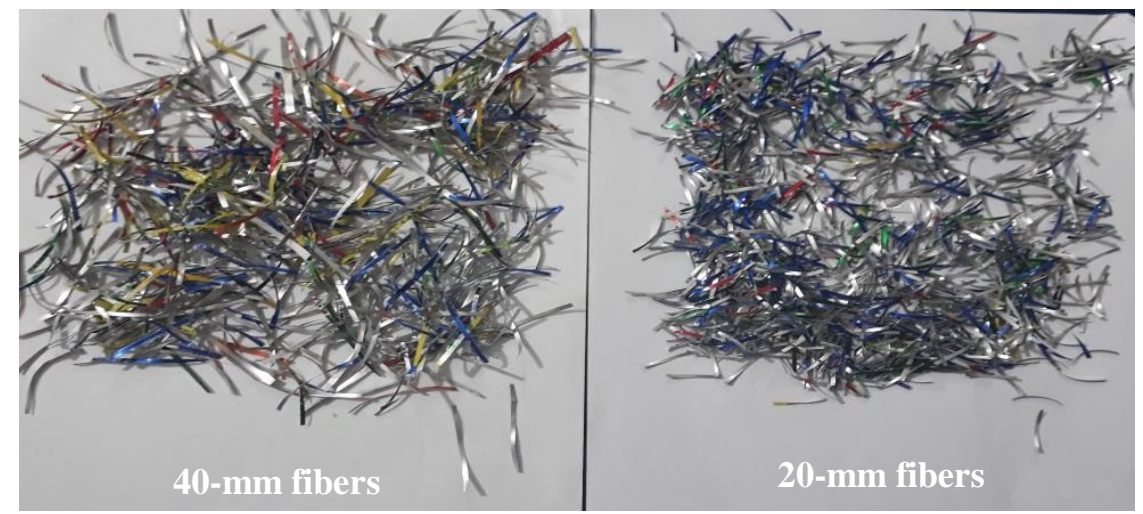

Figure 1. Waste aluminum fibers

The mix proportions details are illustrated in Table 1. Water cement ratio was variable in order to keep the slump constant $75 \pm 5 \mathrm{~mm}$.
Compressive, splitting strengths and modulus of rupture were made according to ASTM C39, ASTM C496 and ASTM C78 respectively.

Table (1): Mix proportion details

\begin{tabular}{cccccccc}
\hline No. & Sample & $\begin{array}{c}\text { Cement } \\
\mathbf{k g} / \mathbf{m}^{3}\end{array}$ & Sand $\mathbf{k g} / \mathbf{m}^{3}$ & $\begin{array}{c}\text { Gravel } \\
\mathbf{k g} / \mathbf{m}^{3}\end{array}$ & $\begin{array}{c}\text { Water } \\
\mathbf{k g} / \mathbf{m}^{3}\end{array}$ & $\begin{array}{c}\text { Dimension of } \\
\text { fibres (Length } \times \\
\text { width } \text { thickness) } \\
\mathbf{m m}\end{array}$ & $\begin{array}{c}\text { Aluminium fibre } \\
\text { (volume } \\
\text { percentage\%) }\end{array}$ \\
\hline 1 & R & 350 & 700 & 1225 & 147 & - & $0 \%$ \\
\hline 2 & FL40P0.5 & 350 & 700 & 1225 & 148 & $40 \times 2 \times 0.25$ & $0.5 \%$ \\
\hline 3 & FL40P0.75 & 350 & 700 & 1225 & 150.5 & $40 \times 2 \times 0.25$ & $0.75 \%$ \\
\hline 4 & FL40P1 & 350 & 700 & 1225 & 154 & $40 \times 2 \times 0.25$ & $1 \%$ \\
\hline 5 & FL20P0.5 & 350 & 700 & 1225 & 147 & $20 \times 2 \times 0.25$ & $0.5 \%$ \\
\hline 6 & FL20P0.75 & 350 & 700 & 1225 & 149.5 & $20 \times 2 \times 0.25$ & $0.75 \%$ \\
\hline 7 & FL20P1 & 350 & 700 & 1225 & 150 & $20 \times 2 \times 0.25$ & $1 \%$ \\
\hline
\end{tabular}

While impact resistance was evaluated using seven $500 \times 500 \times 50 \mathrm{~mm}$ two-way concrete slabs as shown in Figure 1. Slabs were reinforced with smooth steel bars of $\Phi 6 \mathrm{~mm}$ spaced $100 \mathrm{~mm}$ in

$68{ }^{1}$ Corresponding author: College of Engineering, University of Anbar, Ramadi, Iraq. 
both directions. The impact load was applied using impact frame shown in Figure 2, which consists of a very rigid steel frame. The main supports of slabs were made from $60 \times 60 \times 5$ L-section. Impact load was applied by iron steel ball of $96 \mathrm{~mm}$ diameter and $4.5 \mathrm{~kg}$ weight, which is falling through guiding steel tube of diameter $110 \mathrm{~mm}$ located at the center of slab, see Figure 3.

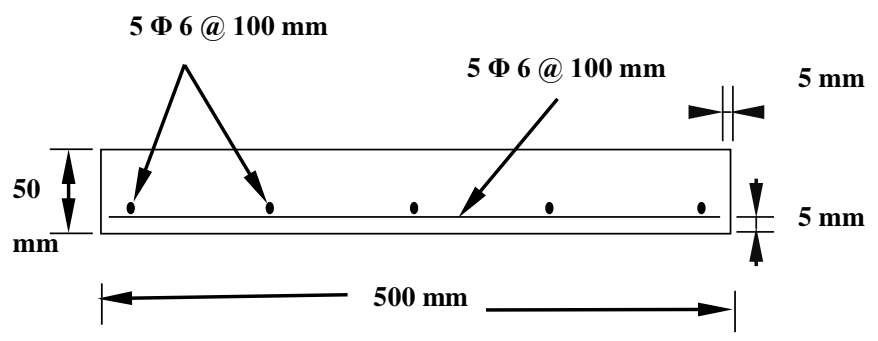

Figure 2. Slabs reinforcement details

Bond strength between steel reinforcement and surrounding concrete incorporating aluminum fibers was evaluating using pull-out test. The specimens were prepared according to
RILEM RC6. $\Phi 10 \mathrm{~mm}$ steel bar embedded in $100 \times 100 \times 100 \mathrm{~mm}$ concrete specimens were used, see Figure 3.

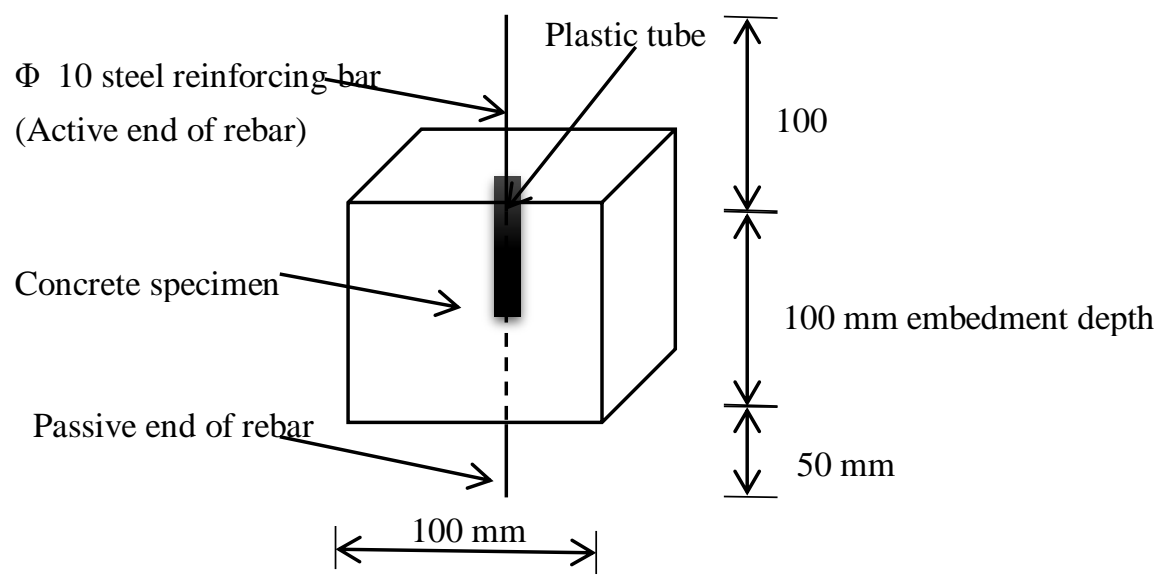

Fig. (3): Dimensions and details of specimen for pullout test

\section{RESULTS AND DISCUSSIONS}

\subsection{Compressive and splitting tensile strength}

Cylinder specimens of $150 \mathrm{~mm}$ diameter and $300 \mathrm{~mm}$ height were used for compressive strength evaluation by subjected to axial compression load at constant rate of loading about $14 \mathrm{MPa} / \mathrm{min}$ until the failure of cylinder specimen. Test results are shown in Table 2. It can see that compressive strength are slightly influenced by fiber added for both fiber length up to $0.75 \%$ while a slight reduction was notice at $1 \%$ waste aluminum fibers. A more ductile failure was notice for all specimens incorporating fibers.

For splitting tensile strength evaluation, cylinder specimens of $100 \mathrm{~mm}$ diameter and 200 $\mathrm{mm}$ height were used and subjected to compression to measure the effect of fiber on indirect tensile strength (see Figure 4). Results show an improvement in splitting tensile 
strength especially for $0.75 \%, 40 \mathrm{~mm}$ fibers, which was $29.56 \%$, compared to the reference as shown in Table 2 and Figure 5. Any increased in strength after first crack is due to subsequent multiple cracking because of fibers bridging action result in loading transfer to other sections instead of localizing at single crack [Rathod 2014]. Long length fibers were exhibited an excellent cracks resistance and reduced micro cracks propagations.

Table (2): Compressive and splitting strengths results

\begin{tabular}{|c|c|c|c|c|c|c|}
\hline No. & Sample & $\begin{array}{l}\text { Compressive } \\
\text { strength } \mathrm{MPa}\end{array}$ & $\begin{array}{l}\text { Experimental } \\
\text { Splitting tensile } \\
\text { strength } \mathrm{MPa}\end{array}$ & $\begin{array}{l}\text { Percentages of } \\
\text { increasing } \%\end{array}$ & $\begin{array}{l}\text { Predicted by } \\
\mathrm{ACl} \text { equation } \\
0.56 \sqrt{f^{\prime} c}\end{array}$ & $\begin{array}{c}\text { Experimental/ } \\
\text { predicted }\end{array}$ \\
\hline 1 & $\mathrm{R}$ & 25 & 2.74 & - & 2.8 & 0.98 \\
\hline 2 & FL40P0.5 & 25.8 & 2.92 & $6.57 \%$ & 2.84 & 1.03 \\
\hline 3 & FL40P0.75 & 24 & 3.45 & $26 \%$ & 2.74 & 1.25 \\
\hline 4 & FL40P1 & 22.5 & 3.15 & $15 \%$ & 2.66 & 1.18 \\
\hline 5 & FL20P0.5 & 26 & 2.85 & $4 \%$ & 2.86 & 0.99 \\
\hline 6 & FL20P0.75 & 24 & 3.08 & $12.4 \%$ & 2.74 & 1.12 \\
\hline 7 & FL20P 1 & 22.2 & 2.98 & $8.76 \%$ & 2.64 & 1.13 \\
\hline
\end{tabular}

Where; $\mathrm{R}=$ reference mix; $\mathrm{F}=$ fiber; $\mathrm{L}=$ length of fiber; $\mathrm{P}=$ percentage of fibers

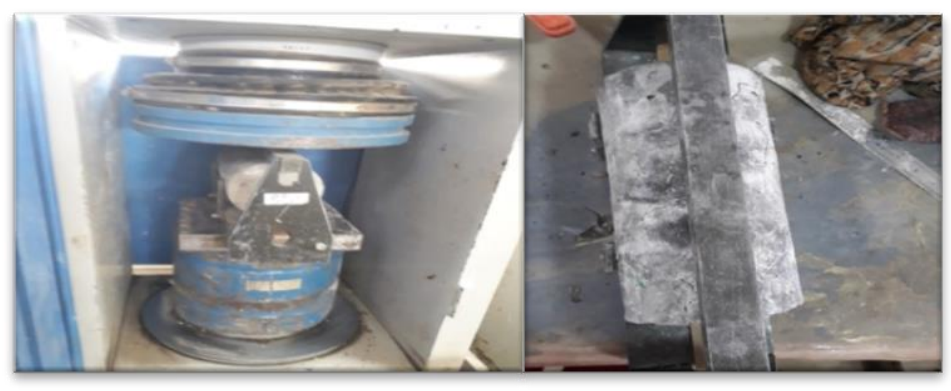

Fig. (4): Specimens for splitting tensile strength evaluation

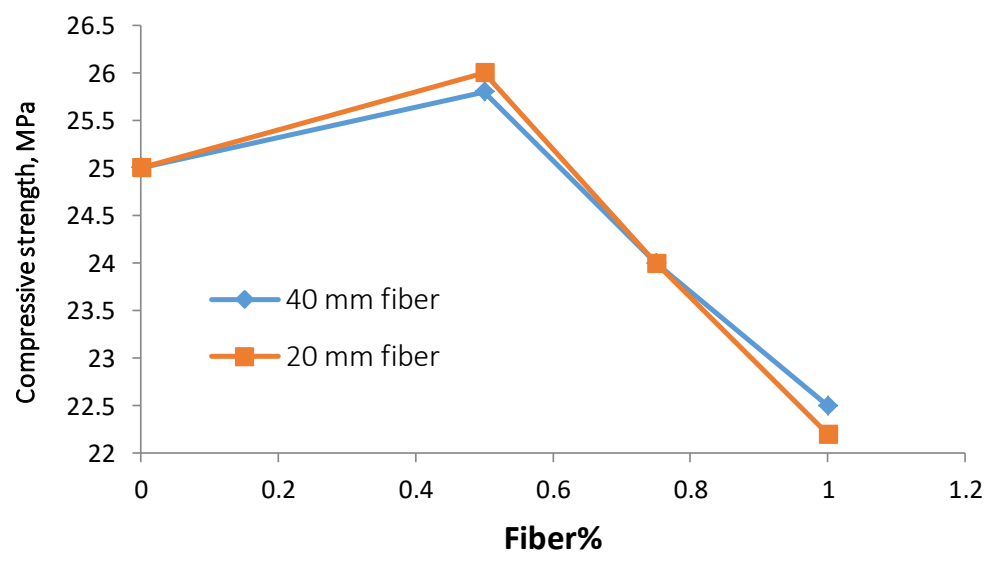

Fig. (5): Compressive strength vs. aluminum content and length 
Table 2 shows a variation between the experimental results and the values rely on equation suggested by ACI code for specimens with waste aluminum fibers especially for fibers content equal and greater than $0.75 \% 40 \mathrm{~mm}$ length fibers. While the experimental results for reference mix and $0.5 \% 20 \mathrm{~mm}$ length fibers is similar to values calculated by ACI equation, see Figure 6. The ACI equation dependent on compressive strength but fibers slightly affected compressive strength compared to tensile one then ACI equation underestimated the tensile strength of fiber concrete.

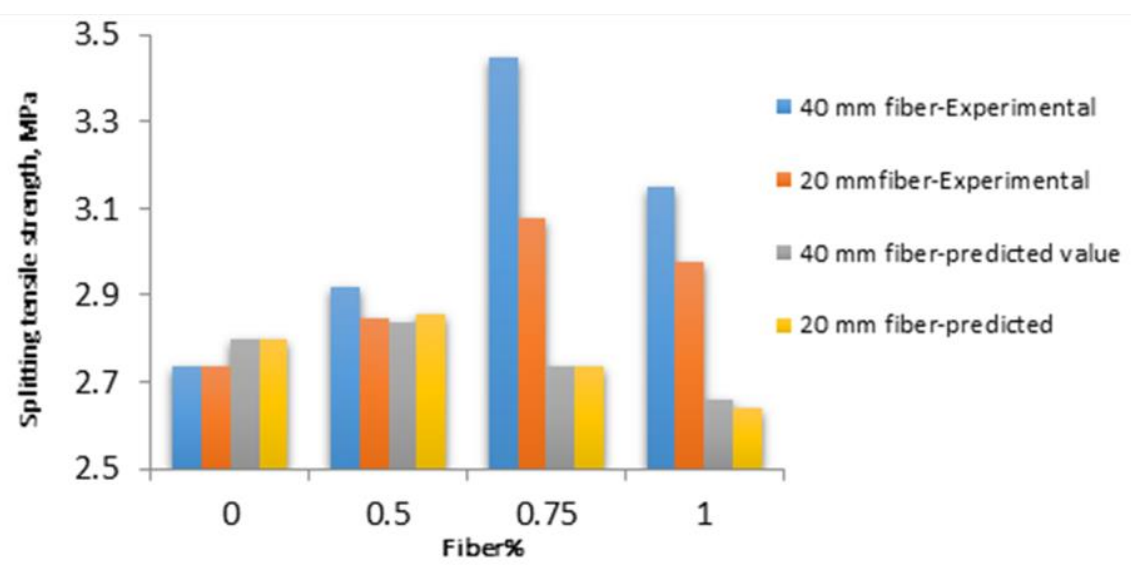

Fig. (6): Experimental splitting tensile strength vs. predicted splitting tensile strength by ACI equation

\subsection{Load-deflection and modulus of rupture}

Plain concrete prisms of

$100 \mathrm{~mm} * 100 \mathrm{~mm} * 500 \mathrm{~mm}$ dimensions were cast and subjected to four-point loading system, see Figure 7. The flexural response of specimen due to the concentrated load at the center was obtained by recording deflection with corresponding load at the mid-span of the prism as shown in Figures 9. Results were represented as flexural strength versus deflection. At a constant rate of loading the loading and, deformation were measured until the final failure of the specimen.

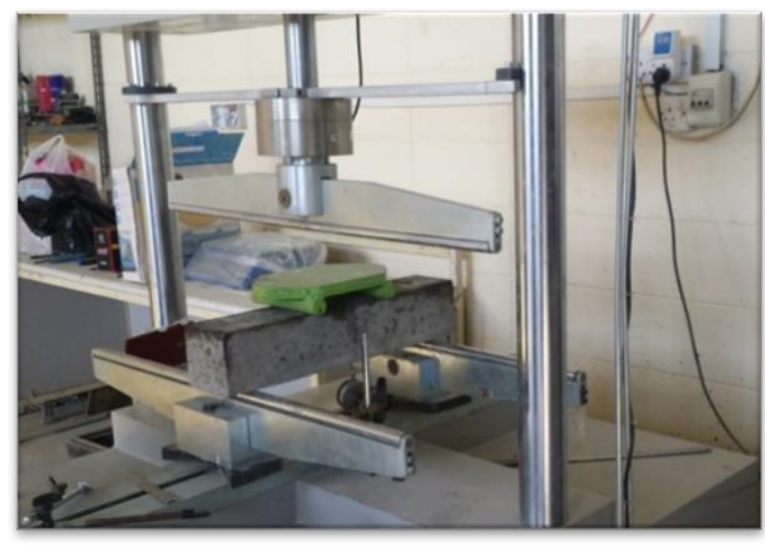

Fig. (7): Specimens for load—deflection and modulus of rupture evaluation test 
From load deflection curves, it is a clear that the behavior of plain specimens without fibers is very brittle and the failure suddenly happened after small deflection. While adding fibers transfers the behavior from brittle one to more ductile and the failure happened gradually. The $0.75 \%$ fibers with $40 \mathrm{~mm}$ length give the more ductile behavior. Flexural strength to deflection relationships are shown in Figure 8. Regardless of length of fibers, concrete containing aluminum fibers demonstrated an increased in modulus of rupture with increased fibers content. At $0.75 \%$ and $1 \%$ fibers, the specimens failed at larger loads and smaller deflection compared to reference one. While concrete containing $0.5 \%$ fibers showed a gradual increase in the deformation capacity for a given load and its behavior closed to reference one. Reference specimens failed without warning due to brittleness nature of concrete that led to low flexural strength. Increasing in modulus of rupture due to adding fibers because fibers ability to restrict the formation, widening and propagation of cracks and a ductile behavior will be observed because of bridging action of fibers across the cracks [Jhatial et al 2018].
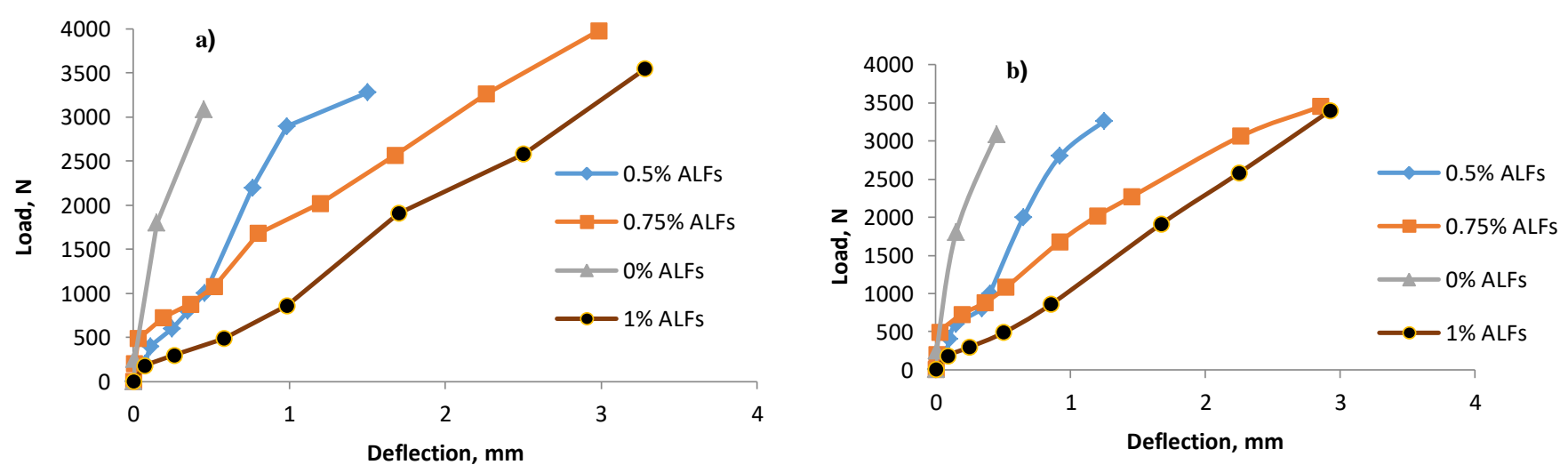

Fig. (8): Flexural strength verse deflection for; a) $40 \mathrm{~mm}$ length aluminum fibers b) $20 \mathrm{~mm}$ length aluminum fibers

Table 3 shows percentages increase in modulus of rupture compared to reference one also a comparison between experimental results of modulus of rupture and the one predicted using ACI cod equations. Variation between the experimental results and the values predicted by ACI code especially for $0.75 \% 40 \mathrm{~mm}$ length fibers. As it was mentioned before ACI equation dependent on compressive strength but fibers slightly affected compressive strength compared to tensile one then ACI equation underestimated the tensile strength of fiber concrete (See Figure 9). 
Table (3): Compressive strength and modulus of rupture results

\begin{tabular}{|c|c|c|c|c|c|c|}
\hline \multirow{2}{*}{$\begin{array}{c}\text { No. } \\
\text { of } \\
\text { Mix }\end{array}$} & \multirow[t]{2}{*}{ Sample } & \multirow[t]{2}{*}{$\begin{array}{l}\text { Compressive } \\
\text { strength, MPa }\end{array}$} & $\begin{array}{l}\text { Experimental } \\
\text { modulus of }\end{array}$ & \multirow[t]{2}{*}{$\begin{array}{l}\text { Percentages of } \\
\text { increasing } \%\end{array}$} & $\begin{array}{l}\text { Predicted by } \\
\mathrm{ACl} \text { equation }\end{array}$ & \multirow[t]{2}{*}{$\begin{array}{c}\text { Experimental / } \\
\text { predicted }\end{array}$} \\
\hline & & & rupture $\mathrm{MPa}$ & & $0.62 \sqrt{f^{\prime} c}$ & \\
\hline 1 & $\mathrm{R}$ & 25 & 3.08 & - & 3.1 & 0.99 \\
\hline 2 & FL40P0.5 & 25.8 & 3.28 & 6.5 & 3.15 & 1.04 \\
\hline 3 & FL40P0.75 & 24 & 3.98 & 29.2 & 3.04 & 1.31 \\
\hline 4 & FL40P1 & 22.5 & 3.55 & 15.2 & 2.94 & 1.21 \\
\hline 5 & FL20P0.5 & 26 & 3.26 & 5.84 & 3.16 & 1.03 \\
\hline 6 & FL20P0.75 & 24 & 3.45 & 12.0 & 3.04 & 1.13 \\
\hline 7 & FL20P 1 & 22.2 & 3.40 & 10.4 & 2.92 & 1.16 \\
\hline
\end{tabular}

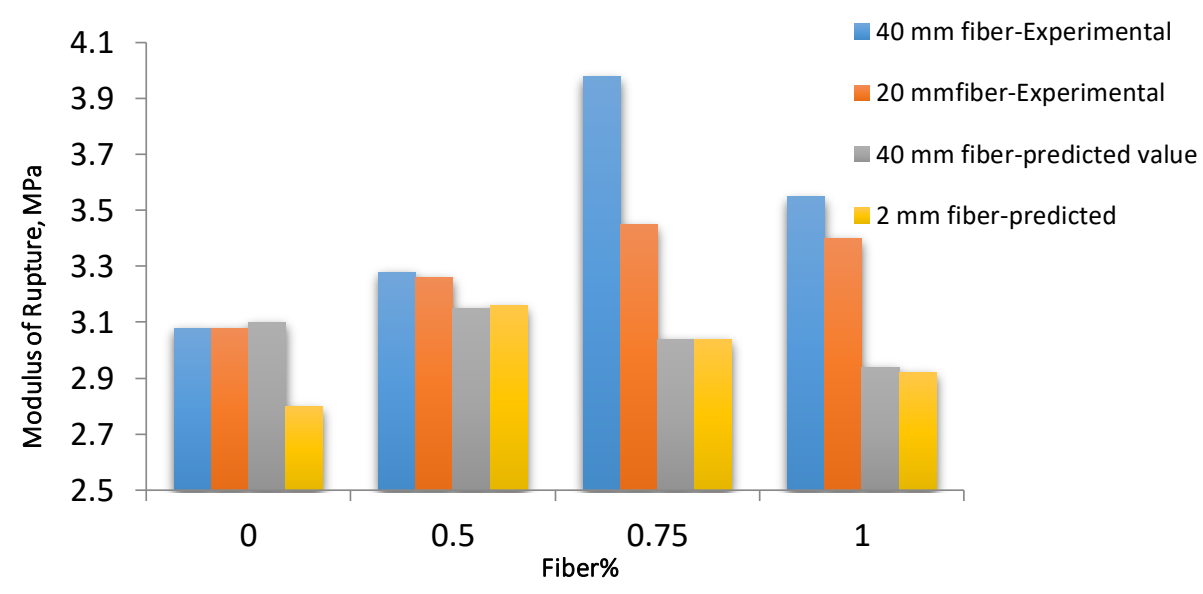

Fig. (9): Experimental modulus of rupture vs. predicted modulus of rupture by ACI equation

\subsection{Impact resistance}

Impact resistance for waste aluminum fibrous concrete was evaluated. Impact load were applied by $4.5 \mathrm{~kg}$ hammer dropped repeatedly from a $450 \mathrm{~mm}$ height, which located at the center of the top surface of the concrete specimens. The impact energy capacity (IEC) was calculated using equation 1 as follow:
IEC $=$ No. of blows $\times$ Mass of ball $(4.5 \mathrm{~kg})$ $\times 9.8 \mathrm{~m} / \mathrm{s}^{2} \times$ ball falling distance $(0.45 \mathrm{~m})$

Number of blows at first visible crack and failure with corresponding crack width and mid-span deflection were recorded. In addition, Energy absorbed was calculated according to equation 1.These results were recorded in Tables 4 and 5 and graphically in Figures 10 and 11 . 
Table (4): Number of blows required to cause first crack and failure with corresponding crack width

\begin{tabular}{|c|c|c|c|c|c|c|c|}
\hline $\begin{array}{c}\text { No. } \\
\text { of } \\
\text { Mix }\end{array}$ & Sample & $\begin{array}{c}\text { No of blows } \\
\text { at first } \\
\text { crack }\end{array}$ & $\begin{array}{l}\text { \%increasing } \\
\text { in No of } \\
\text { blows at first } \\
\text { crack }\end{array}$ & $\begin{array}{l}\text { Width of } \\
\text { first crack, } \\
\text { mm }\end{array}$ & $\begin{array}{l}\text { No of blows } \\
\text { at failure }\end{array}$ & $\begin{array}{l}\text { \%increasing } \\
\text { in No of } \\
\text { blows at } \\
\text { failure }\end{array}$ & $\begin{array}{c}\text { Maximum } \\
\text { crack width } \\
\text { at failure, } \\
\text { mm }\end{array}$ \\
\hline 1 & $\mathrm{R}$ & 2 & - & 0.18 & 8 & -- & 0.5 \\
\hline 2 & FL40P0.5 & 3 & 50 & 0.13 & 13 & 62.5 & 0.35 \\
\hline 3 & FL40P0.75 & 4 & 100 & 0.08 & 20 & 150 & 0.22 \\
\hline 4 & FL40P1 & 3 & 50 & 0.1 & 18 & 125 & 0.28 \\
\hline 5 & FL20P0.5 & 2 & No increasing & 0.13 & 10 & 25 & 0.42 \\
\hline 6 & FL20P0.75 & 3 & 50 & 0.07 & 16 & 100 & 0.38 \\
\hline 7 & FL20P 1 & 3 & 50 & 0.13 & 14 & 75 & 0.4 \\
\hline
\end{tabular}

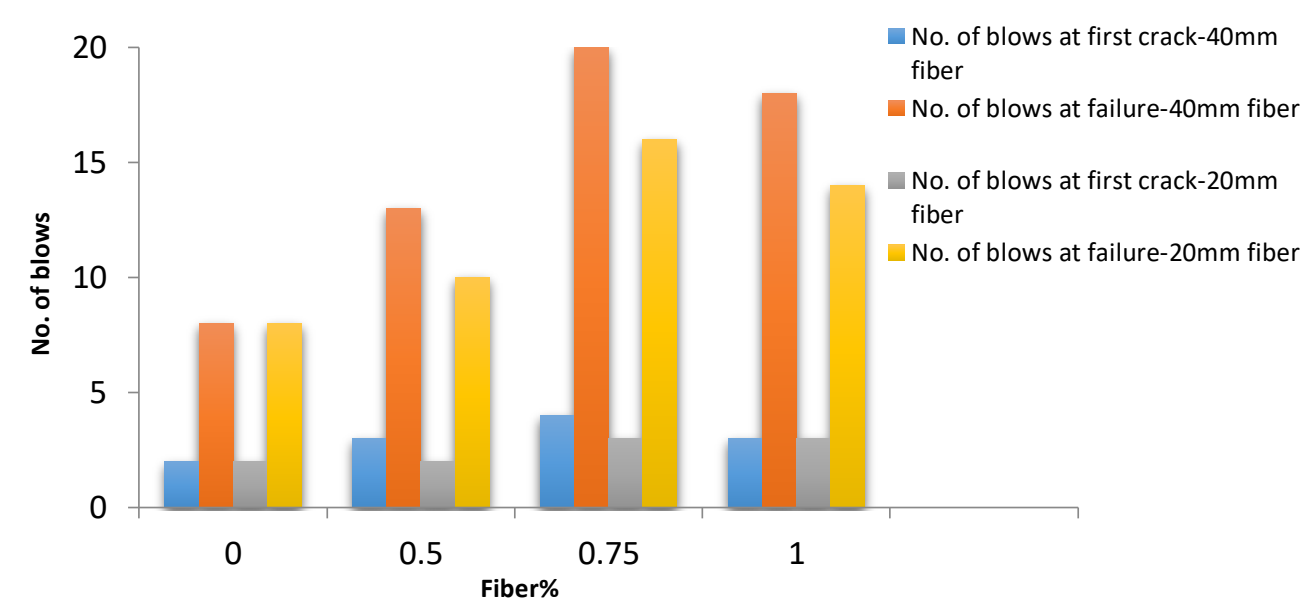

Fig. (10): Number of blows related to ALFs content

Table (5): Energy capacity at first crack and failure with corresponding deflection at mid-span

\begin{tabular}{cccccccc}
\hline $\begin{array}{c}\text { No. } \\
\text { of }\end{array}$ & Sample & $\begin{array}{c}\text { Energy } \\
\text { capacity at } \\
\text { first crack, } \mathbf{~}\end{array}$ & $\begin{array}{c}\text { \%increasing in } \\
\text { energy } \\
\text { capacity at } \\
\text { first crack }\end{array}$ & $\begin{array}{c}\text { Deflection at } \\
\text { first crack, } \\
\mathbf{m m}\end{array}$ & $\begin{array}{c}\text { Energy } \\
\text { capacity at } \\
\text { failure, J }\end{array}$ & $\begin{array}{c}\text { \%increasing } \\
\text { in energy } \\
\text { capacity at } \\
\text { failure }\end{array}$ & $\begin{array}{c}\text { Maximum } \\
\text { Deflection at } \\
\text { failure }, \text { mm }\end{array}$ \\
\hline 1 & R & 39.69 & - & 0.95 & 158.76 & -- & 3.50 \\
\hline 2 & FL40P0.5 & 59.54 & 50 & 0.892 & 257.99 & 62.5 & 2.25 \\
\hline 3 & FL40P0.75 & 79.38 & 100 & 0.72 & 396.9 & 150 & 1.50 \\
\hline 4 & FL40P1 & 59.54 & 50 & 0.80 & 357.21 & 125 & 1.85 \\
\hline 5 & FL20P0.5 & 39.69 & No increasing & 0.86 & 198.45 & 25 & 2.65 \\
\hline 6 & FL20P0.75 & 59.54 & 50 & 0.84 & 282.24 & 100 & 2.25 \\
\hline 7 & FL20P1 & 59.54 & 50 & 0.85 & 277.83 & 75 & 3.22 \\
\hline
\end{tabular}




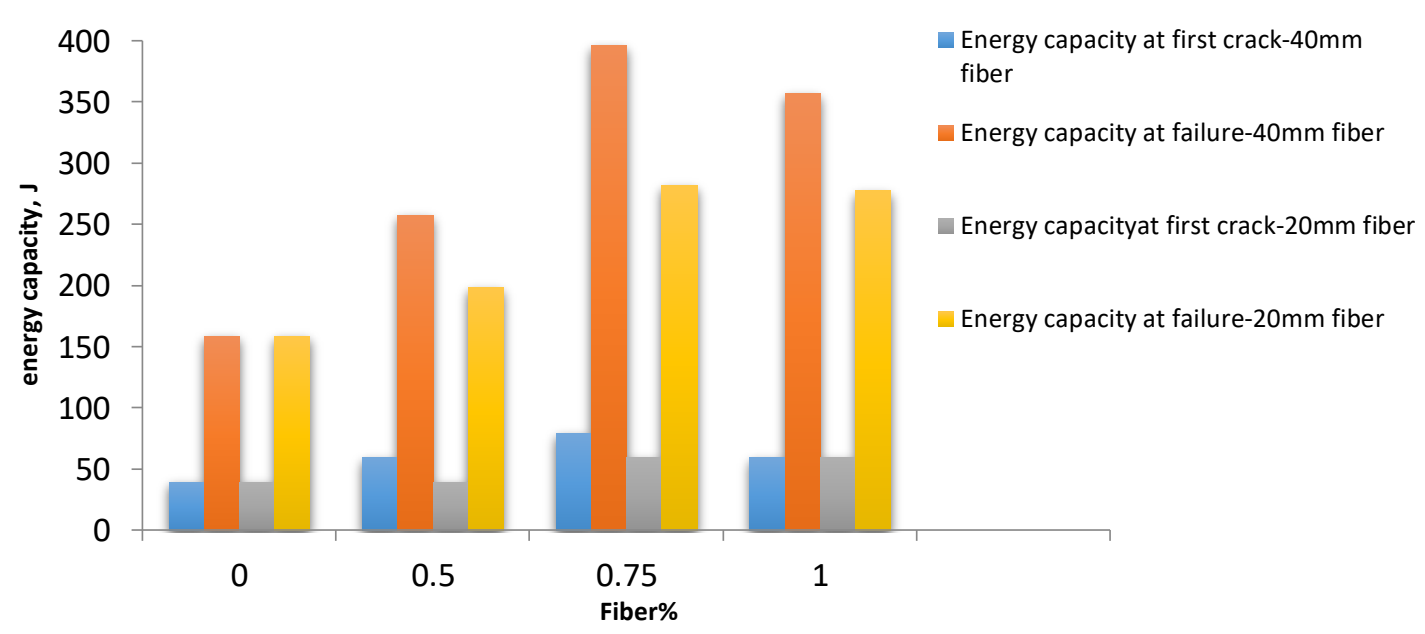

Fig. (11): Energy capacity related to fiber content

The results showed that inclusion of aluminum fibers led to an increase in impact resistance of concrete slabs regardless of fibers length. This increase was evaluated by increasing the number of blows required to cause first crack and that required for failure. Results refereed to 40-mm fibers are more effective than 20 -mm fibers. For both fibers length the $0.75 \%$ fibers is the best content.

In addition, an increase was notice in impact energy as shown in Tables 3 and 4 respectively. This is because the role of aluminum fibers of absorbing additional energy during applied repeated impact load. In addition, the $40-\mathrm{mm}$ length fibers acted more effectively compared to 20-mm length fiber as the results showed. This may because the long fibers have ability to resist the crack propagation after first crack more than the short one, which resulted in multiple, cracks on the surface of slab due to bridging action of these fibers.

In addition, fibers resisted cracks propagation and delayed complete collapse of fibrous concrete slabs. For evaluated crack width, a magnification microscope was used. Moreover, electronic dial-gage was used to deflection measured at mid-span of the slab. Figures 12 and 13 represent the results of measured maximum deflection and crack width, respectively. The adding of this type of fibers allowed being the behavior of slabs more ductile.
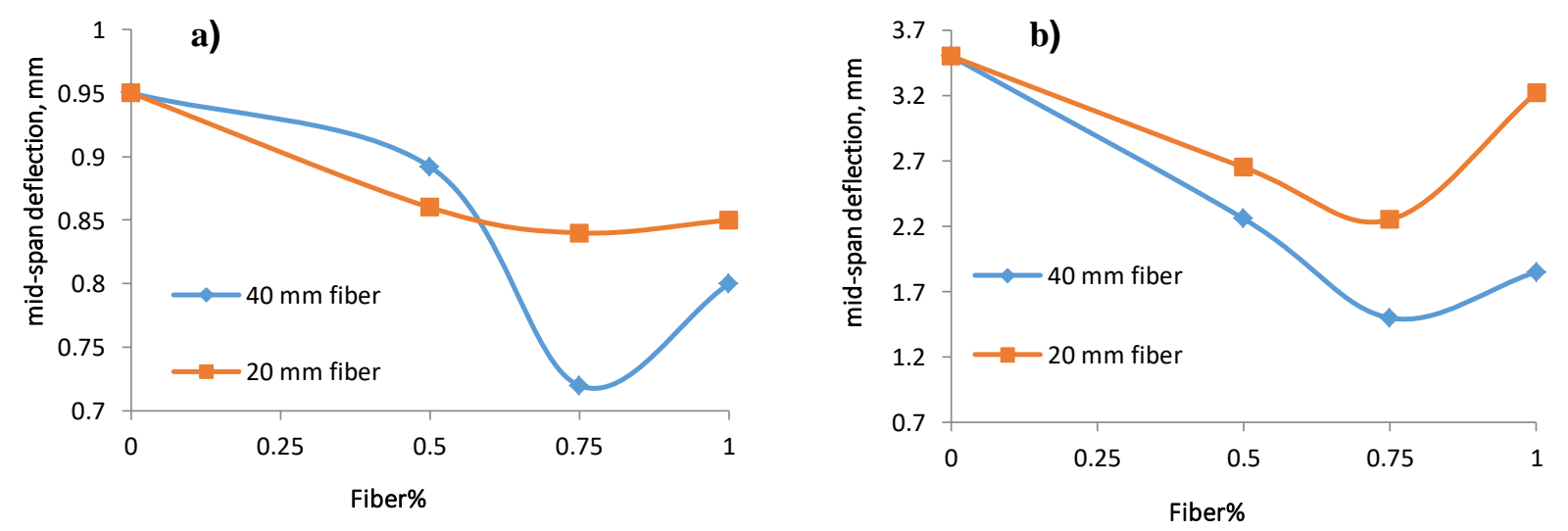

Fig. (12): Maximum mid-span deflection for; a) $40 \mathrm{~mm}$ length aluminum fibers b) $20 \mathrm{~mm}$ length aluminum fibers 

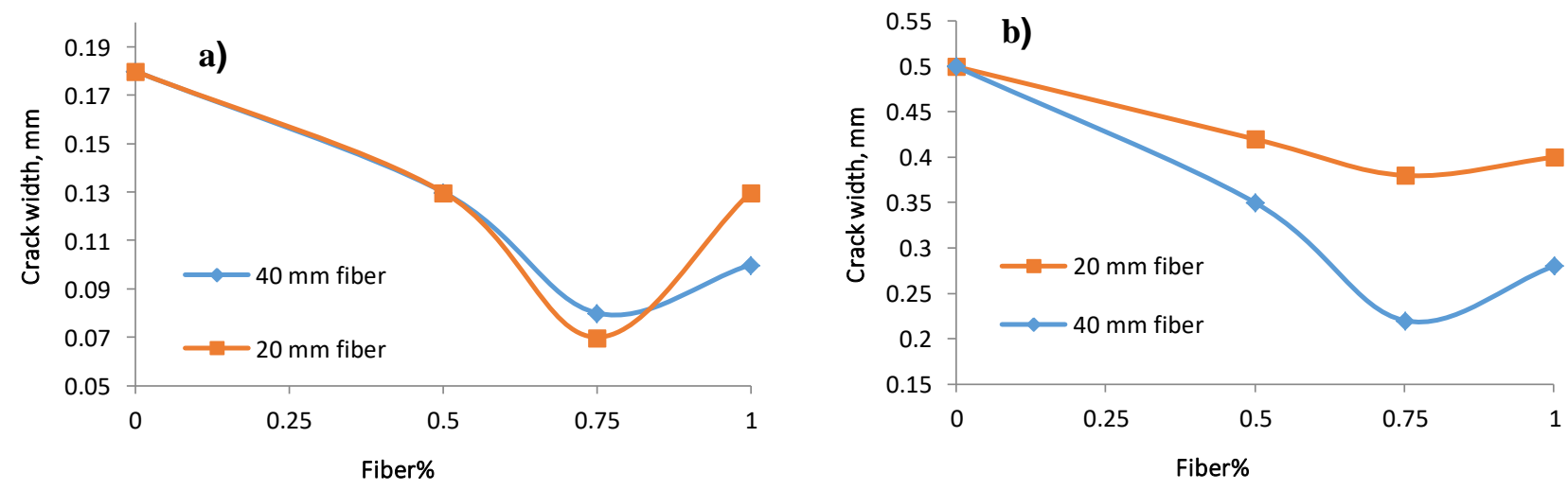

Fig. (13): Maximum crack width at failure for; a) $40 \mathrm{~mm}$ length aluminum fibers b) $20 \mathrm{~mm}$ length aluminum fibers

The diameter of punching area at failure is wider for reference slab than those incorporating fibers. In addition, the slabs that contain 40-mm fibers the diameter of failure area is smaller than those for 20-mm fibers.

\subsection{Bond strength}

Based on experimental data, the bond strength between steel reinforcing bar and concrete was calculated according to following equation 2 ;

$$
\tau=\frac{P}{\pi d l} \quad \ldots \ldots \ldots
$$

Where $\mathrm{P}$ is recorded load, $\mathrm{d}$ is diameter of steel bar $(100 \mathrm{~mm})$ and 1 is length of embedded part of steel bar $(100 \mathrm{~mm})$. Load-slip relations are illustrated in Figure14.
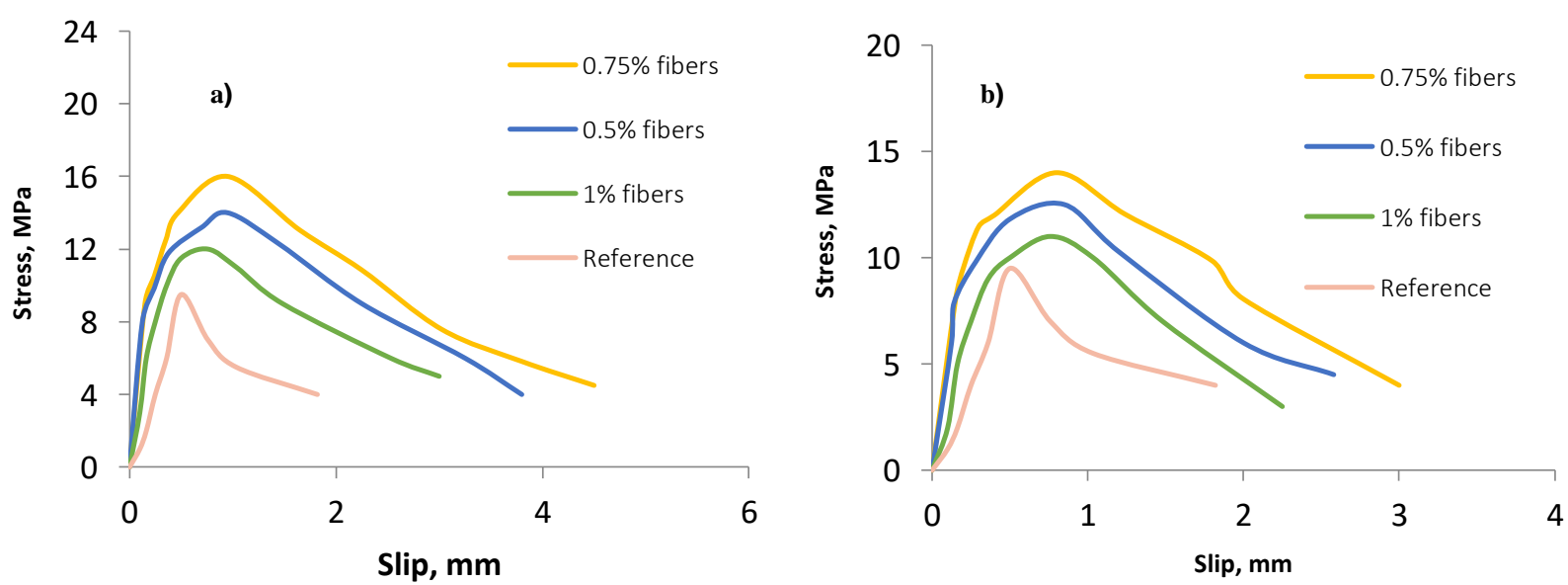

Fig.(14): Maximum crack width at failure for; a) $40 \mathrm{~mm}$ length aluminum fibers b) $20 \mathrm{~mm}$ length aluminum fibers

As shown above $0.75 \%$ aluminum fibers give the highest bond strength for both lengths. The 40-mm fibers are more effective to increase bond strength than shorter fiber length (20-mm). This is due to increase in the embedded length of fibers that led to enhance the pullout strength resistance [Cunha 2010]. All specimens were showed splitting failure. Tensile cracks in concrete parallel to steel reinforcing bar were noticed. This is due to wedging action, which

$76{ }^{1}$ Corresponding author: College of Engineering, University of Anbar, Ramadi, Iraq. 
created a restrained pressure in surrounding concrete, in same time a tensile stresses created around reinforcing bars results in radial splitting cracks and then loss of bond strength with fracture of concrete. In the specimens without fibers failure occurred just after formation of longitudinal splitting cracks and failure was very brittle, sudden and noisy. While those contain fibers, failure developed gradually with behavior that is more ductile.

\section{CONCLUSIONS}

1. Compressive strength slightly influenced by fiber added for both fibers lengths (40 and 20 $\mathrm{mm}$ ) up to $0.75 \%$ while a slight reduction was notice at $1 \%$ waste aluminum fibers.

2. Results show an improvement in splitting tensile strength especially for $0.75 \%, 40 \mathrm{~mm}$ fibers, which was $29.56 \%$, compared to the reference.

3. Regardless of length of fibers, concrete containing aluminum fibers demonstrated an increased in strength with increased fibers content. At $0.75 \%$ and $1 \%$ fibers, the specimens failed at larger loads and smaller deflection compared to reference one. While concrete containing $0.5 \%$ fibers showed a gradual increase in the deformation capacity for a given load and its behavior closed to reference one.

4. The ACI equation depends on compressive strength in determination of splitting strength. But fibers slightly affected compressive strength compared to tensile one while splitting and flexural strengths are sensitive to fibers then ACI equation underestimated the tensile strength of fiber concrete.

5. Inclusion of aluminum fibers led to an increase in impact resistance of concrete slabs regardless of fibers length also an increase was notice in impact energy

6. $0.75 \%$ aluminum fibers give the highest bond strength for both lengths. Moreover, in the specimens without fibers failure occurred just after formation of longitudinal splitting cracks and failure was very brittle, sudden and noisy. While those contain fibers, failure gradually developed with behavior that is more ductile.

7. $40 \mathrm{~mm}$ length fiber was more effective in improvement than $20 \mathrm{~mm}$ fiber length.

\section{REFERENCE}

ACI committee 318. (2019). Building Code Requirements for Structural Concrete (ACI 318-19) and Commentary (ACI 318R-19), American Concrete Institute, Farmington Hills. 623.

Ankur C. Bhogayata, Narendra K. Arora (2017). Fresh and strength properties of concrete reinforced with metalized plastic waste fibers. Construction and Building Materials. 146. 455-463.

http://dx.doi.org/10.1016/j.conbuildmat.2017.04.095 Ashfaque Ahmed Jhatial, Samiullah Sohu, Nadeem-ul-Karim Bhatti, Muhammad Tahir Lakhiar, Raja Oad. (2018). Effect of steel fibers on the compressive and flexural strength of concrete. International Journal of Advanced and Applied Sciences, 5(10): 16-21

ASTM: C39, (2005), "Compressive Strength of Cylindrical Concrete Specimens", American Society of Testing and Material International.

ASTM C496-2005 Splitting tensile Strength of Cylindrical Concrete Specimens", American Society of Testing and Material International

ASTM C78, (2002), "Standard Test Method for Flexural Strength of Concrete (Using Simple Beam with Two-Point Loading)", American Society of Testing and Material International

Aziz K. I., Hama S. M., Kuhair H. M. (2018). Effeciency of Waste Plastic Fiber on Behavior of Composite Steel Plate- Concrete Push Out Test " 11th International Conference on Developments in eSystems Engineering (DeSE). 335-339. DOI 10.1109/DeSE.2018.00066

Aziz K. I., Hama S. M., Kuhair H. M. (2019). Effect of PET Fibers on Mechanical Properties, 
Stress-Strain Relationship and Drying

Shrinkage of Concrete. REVISTA AUS 26-1.

DOI:10.4206/aus.2019.n26-1.31

Behera,G.C. ， Behera,R.K (2015). Increase in Strength of Concrete by Using Bottle Caps", International Research Journal of Engineering and Technology (IRJET). 02(03). 1937- 1942.

Bhogayata, A.C., Arora, N.K. (2018). Impact strength, permeability and chemical resistance of concrete reinforced with metalized plastic waste fibers. Construction and Building Materials 161. 254-266.

https://doi.org/10.1016/j.conbuildmat.2017.11.135

Cunha, V. M. (2010). "Steel fibre reinforced self-compacting concrete (from micromechanics to composite behavior)." Ph.D. thesis, Univ. of Minho, Braga, Portugal.

Diptikar Behera, Abdulkadir Enday Ahmed, Nigate Chala (2018). Innovative and Sustainable Application of Soft Drink Bottle Caps as Fiber in Concrete Structures" International Journal of Advance Engineering and Research Development. 5(02)

Fraternalia F., Ciancia V., Chechile R., Feo G.L. (2011). Experimental study of the thermo-mechanical properties of recycled PET fiber reinforced concrete", Composite Structures, 93(9), pp. 2368-2374. https://doi.org/10.1016/j.compstruct.2011.03.0 25

Hama S. M. (2017). Improving mechanical properties of lightweight Porcelanite aggregate concrete using different waste material" International Journal of Sustainable Built Environment; 6(1), 81-90.

http://dx.doi.org/10.1016/j.ijsbe.2017.03.002

Hama S. M. (2015). Efficiency of Using Steel Fibers Taken From Old Tyres in Polymer Concrete Comparison with Using Imported Fibers ". Yanbu Journal of Engineering \& Science, 10 (1436H). 49-57.

Indradi Wijatmiko, Ari Wibowo, and Christin Remayanti Nainggolan (2019) Strength
Characteristics Of Wasted Soft Drinks Can As Fiber Reinforcement In Lightweight Concrete" International Journal of GEOMATE. 17(60). 31-36. Geotec., Const. Mat. \& Env., DOI: https://doi.org/10.21660/2019.60.4620

Iraqi specification No.6/29-1984 Portland Cement Central Agency for Standardization and Quality Control, Planning Council, Baghdad, Iraq, translated from Arabic edition.

Iraqi specification No.46/2984, “Aggregate from Natural Sources for Concrete", Central Agency for Standardization and Quality Control, Planning Council, Baghdad, Iraq, translated from Arabic edition.

Murali G., VivekVardhan C.M. (2012). Experimental Investigation On Fibre Reinforced Concrete Using Waste Materials", International Journal of Engineering Research and Applications (IJERA). 2(2). 278-283.

Rathod JD., (2014) Effect of Single Fiber Pull Out Test Result on Flexural Performance of ECC. J Civil Environ Eng 4: 140. doi:10.4172/2165$784 X .1000140$

RILEM, T. (1994). RC 6 Bond test for reinforcement steel. 2. Pull-out test, 1983. RILEM recommendations for the testing and use of constructions materials. pp. 218-220.

Silva S.and Prasanthan T. (2019). Application of Recycled PET Fibers for Concrete Floors. Journal of the Institution of Engineers. LII (01). 21-27

Suji P, Chandralekha S.K, Gayathri S. "Effect of Metallic Bottle Cap Fibre Addition on Strength Properties of Concrete" International Journal on Recent Researches in Science, Engineering \& Technology (IJRRSET), Volume 5, Issue 11 November 2017.

Pelissera F., Montedoa O. R. K., Gleizeb P. J. P. , Romanb H. R. (2012). Mechanical Properties of Recycled PET Fibers in Concrete. Materials Research. 15(4): 679-686. DOI: 10.1590/S1516-14392012005000088 